\title{
ENTREPRENEURIAL MANAGEMENT AND EDUCATION: Experienc- es in the application of business simulations
}

\section{PODUZETNIČKI MENADŽMENT I OBRAZOVANJE: Iskustva u prim- jeni poslovnih simulacija}

\author{
Ines Milohnić, Ivana Licul \\ Faculty of Tourism and Hospitality Management, University of Rijeka, Opatija, Croatia \\ Fakultet za menadžment u turizmu i ugostiteljstvu, Sveučilište u Rijeci, Opatija, Hrvatska
}

\section{Abstract}

The key characteristics of entrepreneurs of the twenty-first century include the willingness to take responsibility, ability to develop strategic visions and objectives, and powerful motivation to succeed. The challenges of the entrepreneurial environment are mirrored in the higher education system that has the task of preparing students for the unpredictable and turbulent labour market. Business decisions are vital for the survival of an enterprise, together with the entrepreneurial functions of project planning, development and execution, as well as the ability to adapt to teamwork settings, be proactive and take risks. Accordingly, keeping abreast of innovative and interactive trends in teaching is a crucial element in the overall development of the skills and competencies of future entrepreneurs, in particular, and the teaching process, in general.

The purpose of this paper is to investigate the satisfaction of students with regard to the benefits derived from the application of active teaching methods in an undergraduate university study programme at the Faculty of Tourism and Hospitality Management of the University of Rijeka. Using business simulations in teaching the course "Entrepreneurial Management and Innovation" is an active learning method that allows students to experiment with business strategies, in a risk-free setting, in the strategic areas of managing human resources, capacities, investments, service quality, prices and marketing.

Research for the purposes of this paper was con-
Sažetak

Prihvaćanje odgovornosti, razvijanje strateške vizije i ciljeva te snažna motivacija za uspjeh temeljne su karakteristike poduzetnika 21. stoljeća. Izazovi poduzetničkog okruženja istovremeno su izazovi i visokoškolskog obrazovnog sustava, koji ima obvezu pripremiti studente za nepredvidivo i turbulentno tržište rada. Poslovne odluke ključne su za opstanak poduzeća, pri čemu se posebno naglašavaju poduzetničke funkcije planiranja, razvijanja i provedbe projekata, kao i vještine prilagodljivosti rada $u$ timu, uz proaktivno djelovanje i sposobnost preuzimanja rizika. Sukladno tome, praćenje inovativnih i interaktivnih trendova $u$ podučavanju, čini ključni element sveukupnog razvoja vještina i kompetencija budućih poduzetnika, ali i nastavnog procesa općenito. Svrha ovoga rada sadržana je $\mathrm{u}$ istraživanju zadovoljstva studenata $\mathrm{u}$ pogledu koristi primjene aktivnih metoda podučavanja na preddiplomskom sveučilišnom studiju Fakulteta za menadžment $u$ turizmu i ugostiteljstvu Sveučilišta u Rijeci. Poslovna simulacija primijenjena $\mathrm{u}$ sklopu nastave kolegija "Poduzetnički menadžment i inovacije” predstavlja aktivnu metodu učenja, koja omogućuje eksperimentiranje $\mathrm{s}$ poslovnim strategijama $\mathrm{u}$ nerizičnoj okolini, a povezano sa strateškim područjima upravljanja ljudskim resursima, kapacitetima, investicijama, kvalitetom usluge, cijenom i marketingom. Istraživanje za potrebe ovoga rada provedeno je među redovitim studentima druge godine preddiplomskog sveučilišnog 
ducted among second-year, full-time students of the undergraduate university study programme, using the survey method and a pre-designed structured questionnaire. Research results point to a high level of student satisfaction with regard to the innovative approach to teaching and the benefits of active learning methods used, which the respondents distinctly prefer relative to traditional seminar-based teaching. The study indicates a high level of satisfaction with the benefits of simulations in the process of developing entrepreneurial spirit and managerial skills but also a lower level of satisfaction in the segment of complexity in connection with previously acquired knowledge.

The results of this study can contribute to improving the existing knowledge and to expanding the use of active learning through the application of a hybrid learning model that opens up opportunities for achieving the ultimate goal of enhancing the employability of students and increasing their competitiveness.

\section{INTRODUCTION}

The incremental evolution of society and market economies is driving the need for new knowledge and innovative, entrepreneurial competencies as factors of future development. This fact is supported by the conclusions of the report of the World Economic Forum /1/, where economics experts presented a development strategy for jobs and employment in the future while underlining the key skills that would be required of employees by 2020 . Among other skills, experts singled out problem solving, critical thinking, creativity, coordinating with others, judgement and decision making, negotiating skills and cognitive flexibility. When viewed as the determinants of entrepreneurship, these skill sets prove to be of exceptional importance in the context of key competitive advantages of job seekers. According to $/ 2 /$, entrepreneurship is a dynamic process of creation and commitment to a specific goal, with the entrepreneur using a combination of resources to take up an initiative, introduce change and create new value. When seen as the ability to transform ideas into action, entrepreneurship is further characterised by studija uz pomoć prethodno kreiranog strukturnog upitnika korištenjem metode anketiranja. Rezultati provedenog istraživanja pokazuju visoku razinu zadovoljstva studenata $u$ segmentu inovativnog pristupa izvođenju nastave i korisnosti primjene aktivnih metoda učenja kojima ispitanici daju izrazitu prednost $\mathrm{u}$ odnosu na klasičnu seminarsku nastavu. Utvrđeno je visoko zadovoljstvo korisnošću simulacija u procesu razvoja poduzetničkog duha i menadžerskih sposobnosti, ali istovremeno i niža razina zadovoljstva u segmentu kompleksnosti a povezano s prethodno stečenim znanjima. Rezultati ovog istraživanja mogu pridonijeti unapređenju postojećih spoznaja i široj primjeni aktivnog učenja korištenjem hibridnog modela učenja čime se otvaraju mogućnosti za ostvarenje konačnog cilja kroz povećanje zapošljivosti studenata i rast njihove konkurentnosti.

innovativeness and risk taking as well as by the ability to plan, organise and coordinate activities to accomplish goals. Because of its multidisciplinary applicability in practice, entrepreneurship has become an imperative of the educational system. As early as 2003, the European Commission in its Green Paper on Entrepreneurship in Europe /3/ highlighted the need to further encourage education in the field of entrepreneurship by fostering an entrepreneurial mind-set and raising the awareness of the importance of developing entrepreneurial skills. Regarding the acquisition and development of skills, /4/ point out the importance of modern didactic-method tools in teaching that, unlike traditional methods, enable active engagement in the teaching process. Learning through business simulations was developed in response to the ongoing search for new methods for conveying knowledge. In the recent academic and professional literature, a very broad approach is taken to the phenomenon of innovative teaching methods and the papers that analyse the determinants of learning through business simulations cover a wide multidisciplinary range. /5/ note that business simulations are 
effective in all phases of the knowledgecreation cycle because their application encourages the creation of experiences from the lessons learned. /6/ agree with this and single out the combination of input, application, reflection and feedback as the key advantages of business simulations. /7/ writes that business simulations can be seen as an interactive learning environment in which the participants are actively involved in experiments, roles and simulations of everyday work situations or development scenarios. The application of business simulations is particularly useful in developing skills and competencies in the field of entrepreneurial management. This statement provides the research framework of this paper, which seeks to examine the satisfaction of students with the benefits of using business simulations in the course "Entrepreneurial Management and Innovation" as part of the undergraduate university study programme at the Faculty of Tourism and Hospitality Management of the University of Rijeka. The study also aims to investigate whether the characteristics of business simulations affect the students' satisfaction with the use of business simulations. Accordingly, two research questions were developed:

1. Do differences exist between expectations and overall satisfaction with the experience of using business simulations?

2. What are the key advantages and disadvantages of business simulations?

The paper comprises five sections. After the introduction, an overview of fundamental concepts based on previous studies is provided. The third section explains the research methodology. Research results are presented in the fourth section. The last part, Conclusion, synthesises the entire study from the theoretical and applicative perspectives of the application of findings.

\section{LITERATURE REVIEW}

Proactive technological development, dynamic changes in society and a turbulent market economy have created conditions in which survival is considerably more difficult without entrepreneurial knowledge, skills and compe- tencies. In recent times, this has made entrepreneurship the subject of research of many academic and professional papers. According to $/ 8$ / entrepreneurial activities and a specific entrepreneurial mind-set are indeed crucial skills of the twenty-first century. /9/ emphasize the importance of entrepreneurship for the success of today's societies because of its impacts on economic and technological development and job creation. Such challenges to entrepreneurs are also challenges to the educational system that is tasked with providing new applicable knowledge and support in developing the entrepreneurial spirit, skills and competencies in the best possible way. To maintain that changes to the structure and functions of universities are essential. /10/ Such adjustments include modern teaching methods, new ways of management and internal organisational changes that contribute towards interdisciplinarity and cooperation with a market economy. These changes in universities and faculties have become a topical phenomenon of research that in the recent literature is discussed from the perspective of innovation /11/; /12/ and entrepreneurship /13/; /14/; /15/; /16/; $/ 17 / ; / 18 / ; 19 /$. The studies mentioned focus on changes in universities that are manifested as forms of fostering innovative and entrepreneurial activities. Innovative and hybrid teaching methods help to improve education in the field of entrepreneurship by enabling the visualisation, experience, understanding and retention of accumulated knowledge. Considering that learning on one's own mistakes is the most expensive way to learn, /20/ underline the need for gaining experience in controlled conditions where consequences are not as painful and costly as in practice. For this reason, business simulations are often used as a methodological tool in teaching and acquiring knowledge. /21/ define business simulations as a set of methods and techniques that make it possible to simulate real systems based on scientific principles and the use of scientific methods and techniques. /22/ see them as the development situations of concrete realities in which participants in different roles acquire responsibilities in an unpredictable environment. It can be concluded that, in conceptual terms, business simulations 
are imitations of reality, creating alternative versions of that reality in controlled conditions and enabling users to acquire a sense of responsibility for their own actions, take a stand on changes, establish objectives and how to accomplish them, and be motivated to succeed. Many authors such as /23/; /24/; /25/; /26/; /27/; /28/; and /29/ have assessed the effectiveness of using business simulations. These authors have reached an almost unified conclusion regarding the benefits of using business simulations in the educational system. As key advantages they list the opportunity for experimental and experiential learning in the controlled conditions of virtual reality, the development of critical thinking skills, stimulation of the cognitive process, analytical thinking, strategy development, teamwork and taking justified risks.

/30/ gives business simulations yet another attribute by describing them as a useful tool in transformational learning resulting from incremental knowledge acquisition. Very simply, /31/ describes the decision process in business simulations as follows. "During each decision round, students make decisions based on whatever knowledge they hold about marketing and business. When they receive the results, they see that the world, including their competitors, did not behave exactly as expected. By studying the inputs and outputs, they try to discern cause and effect, resulting in an updated knowledge base. With this updated information, they consider their options going forward, make projections as to the possible outcomes and choose a set of tactics they believe will have the best results. In short, they question what they think is right". This process of the development of entrepreneurial skills and competence is in line with experiential learning theory $/ 32 /$, according to which knowledge is created through the transformation of experience. /33/ expanded that learning cycle by combining the experiential learning process with business simulation elements and placing special emphasis on their causeeffect links.

The results of previous studies, showing that business simulations yield substantial benefits with regard to the acquisition of entrepreneur- ial skills and competence, were used as a platform for conducting empirical research concerning the satisfaction of students with the use of business simulations in entrepreneurial management classes.

\section{METHODOLOGY}

To accomplish the research objective, empirical research was carried out on a sample of 171 students of the undergraduate study programme at the Faculty of Tourism and Hospitality Management of the University of Rijeka, who used a business simulation as part of the teaching process in the course "Entrepreneurial Management and Innovations". The computer-based business simulation provided the students with a holistic perception of entrepreneurship through the experiential learning of business success factors in the environments of small and medium-sized enterprises. For the purpose of this study, a questionnaire was designed, consisting of two sets questions and comprising a total of 12 closed questions and one open-ended question. The first set of questions aimed to investigate satisfaction with the characteristics of business simulations while the second set sought to measure expectations prior to using the simulation and overall satisfaction achieved upon using the simulation. Respondents were asked to rate their agreement with the statements using a Likert scale, ranging from 1 "I completely disagree" to 5 "I completely agree". The same scale was also used to assess their level of satisfaction. To test the key advantages and disadvantages of implementing business simulations in teaching, an open-ended question was posed, allowing up to three advantages and three disadvantages to be listed. Data were collected during 2016 and 2017 using the survey method and were processed by the appropriate statistical procedures used in the IBM SPSS Statistics 23 software package.

\section{RESEARCH RESULTS}

Presented in this section are measurement items and the results of descriptive statistics. The benefits of using a business simulation in the teaching process were assessed by analys- 
ing the advantages and disadvantages listed by students in the open-ended question. Correlation analysis was performed to test the interrelation between satisfaction with the use of the business simulation and the business simulation's characteristics. Finally, factor analysis was conducted and results are presented.

Table 1: Measurement items and results of descriptive statistics

\begin{tabular}{|c|c|c|c|}
\hline Measurement items $(\mathrm{N}=171)$ & CODE & MEAN & SD \\
\hline $\begin{array}{l}\text { 1. A business simulation fosters an entrepreneurial spirit and managerial } \\
\text { competencies }\end{array}$ & $\mathrm{v} 1$ & 4.22 & .844 \\
\hline $\begin{array}{l}\text { 2. A business simulation makes it easier to understand the theoretical part of } \\
\text { the course }\end{array}$ & v2 & 4.04 & .894 \\
\hline $\begin{array}{l}\text { 3. A business simulation encourages a managerial mind-set and facilitates } \\
\text { decision making }\end{array}$ & v3 & 4.26 & .801 \\
\hline 4. A business simulation is a useful learning method & $\mathrm{v} 4$ & 4.27 & .952 \\
\hline 5. A business simulation is an interesting learning method & v5 & 4.14 & 1.008 \\
\hline 6. Computer skills are needed for using a business simulation & v6 & 4.13 & 1.109 \\
\hline 7. A business simulation is easy to use & v7 & 2.76 & 1.239 \\
\hline $\begin{array}{l}\text { 8. The use of a business simulation has considerable advantages over conven- } \\
\text { tional teaching }\end{array}$ & v8 & 4.52 & .714 \\
\hline 9. New knowledge is acquired through the use of a business simulation & v9 & 4.11 & .933 \\
\hline $\begin{array}{l}\text { 10. The knowledge acquired through the use of a business simulation will be } \\
\text { useful in my future job }\end{array}$ & v10 & 4.12 & .957 \\
\hline 11. Expectations prior to the use of a business simulation & v11 & 3.95 & .853 \\
\hline 12. Satisfaction with the experience of using a business simulation & $\mathrm{v} 12$ & 4.37 & .703 \\
\hline
\end{tabular}

The results of descriptive statistics suggest that students have a high level of satisfaction with regard to the use of a business simulation. The advantage of using a business simulation, in comparison with conventional teaching, was rated with the highest average score of 4.52 $(\mathrm{sd}=.714)$. The students believe that business simulations help to foster an entrepreneurial spirit and managerial competencies $(\mathrm{M}=4.22$, $\mathrm{sd}=.844$ ), pave the way to a managerial mindset and facilitate decision making ( $M=4.26$, $\mathrm{sd}=.801$ ), and make it easier to master the theoretical part of the course $(\mathrm{M}=4.04, \mathrm{sd}=.894)$. The variable with the lowest score refers to the easiness of using business simulations $(\mathrm{M}=2.76$, $\mathrm{sd}=1.239$ ). Particularly interesting are the results of descriptive statistics that point to the differences between prior expectations $(\mathrm{M}=3.95, \mathrm{sd}=.853)$ and satisfaction with the experience of using a business simulation $(\mathrm{M}=4.37, \mathrm{sd}=.703)$. To evaluate the benefits of using business simulations in the teaching process, the advantages and disadvantages listed by students in the open-ended question were analysed. Research results are presented in Figures 1 and 2. 
Ines Milohnić, Ivana Licul: ENTREPRENEURIAL MANAGEMENT AND EDUCATION: Experiences in the application of business simulations

Informatol. 51, 2018., 3-4, 172-181

Figure 1: Advantages of implementing simulations in the teaching process

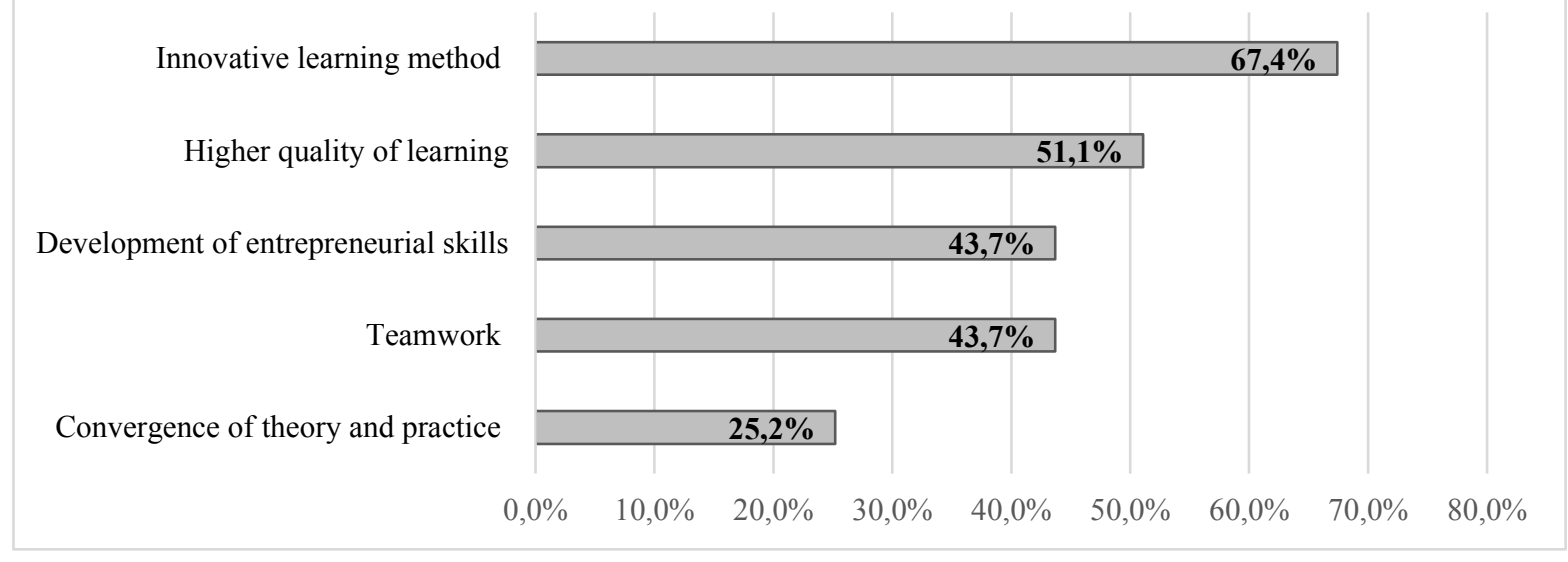

The vast majority of students $(67,4 \%)$ stated innovative learning method as the advantage of business simulations while $51,1 \%$ of students reported higher quality of learning. Of the other advantages, students singled out the development of entrepreneurial skills and teamwork (43,7\% each) and the convergence of theory and practice $(25,2 \%)$.

Figure 2: Disadvantages of implementing simulations in the teaching process

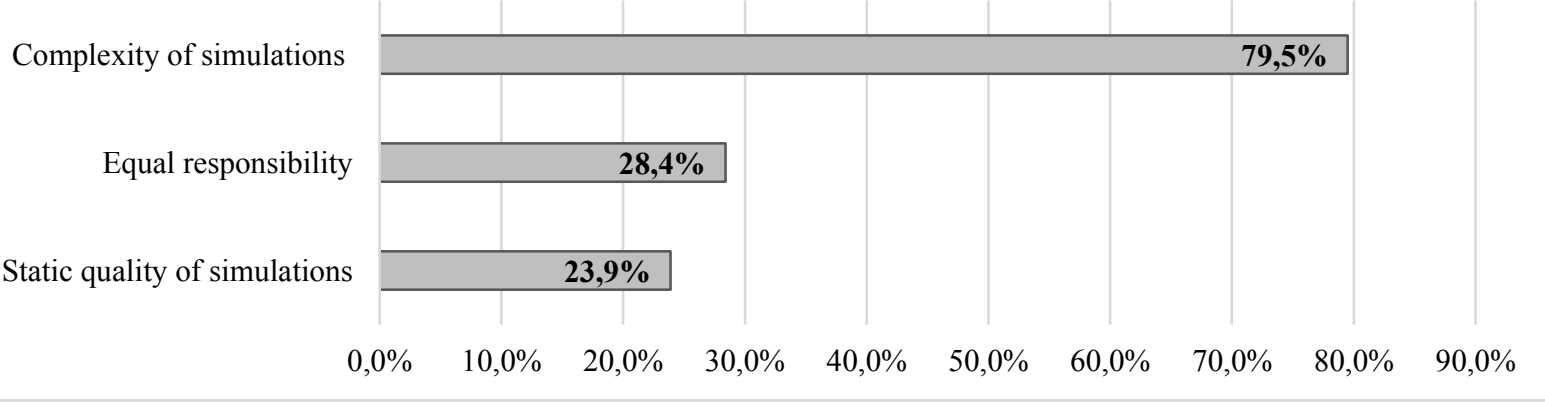

Fully $79,5 \%$ of students reported the complexity of simulations as a disadvantage. This is followed by equal responsibility of team members $(28,4 \%)$, which students consider is often the cause of dissonance in team decision-making. Once they had mastered the logic of the simulation, however, the students were able to suggest innovative solutions to further develop the business simulation by implementing additional variables which could be manipulated to achieve even better business results. Accord- ingly, 23,9\% of the students pointed out the static quality of the business simulation as a disadvantage. For the purpose of studying the relationship between satisfaction with a business simulation and the simulation's characteristics, the correlation between satisfaction with the experience of using the business simulation and the variables of the first set of questions (v1-v10) was analysed. The Pearson correlation coefficient (r) was used to analyse the correlation between the variables.

Table 2: Correlation between satisfaction with the experience of using a business simulation and the characteristics of the simulation $\left(r_{p}\right)$

\begin{tabular}{|c|c|c|c|c|c|c|c|c|c|c|}
\hline Variable & $\mathbf{v 1}$ & $\mathbf{v 2}$ & $\mathbf{v 3}$ & $\mathbf{v 4}$ & $\mathbf{v 5}$ & $\mathbf{v 6}$ & $\mathbf{v 7}$ & $\mathbf{v 8}$ & $\mathbf{v 9}$ & v10 \\
\hline $\begin{array}{c}\text { Satisfaction } \\
\text { with the } \\
\text { experience } \\
\text { of using a } \\
\text { business }\end{array}$ & $.438^{* *}$ & $.456^{* *}$ & $.419^{* *}$ & $.408^{* *}$ & $.465^{* *}$ & $.360^{* *}$ & .090 & $.406^{* *}$ & $.630^{* *}$ & $.512^{* *}$ \\
\hline
\end{tabular}




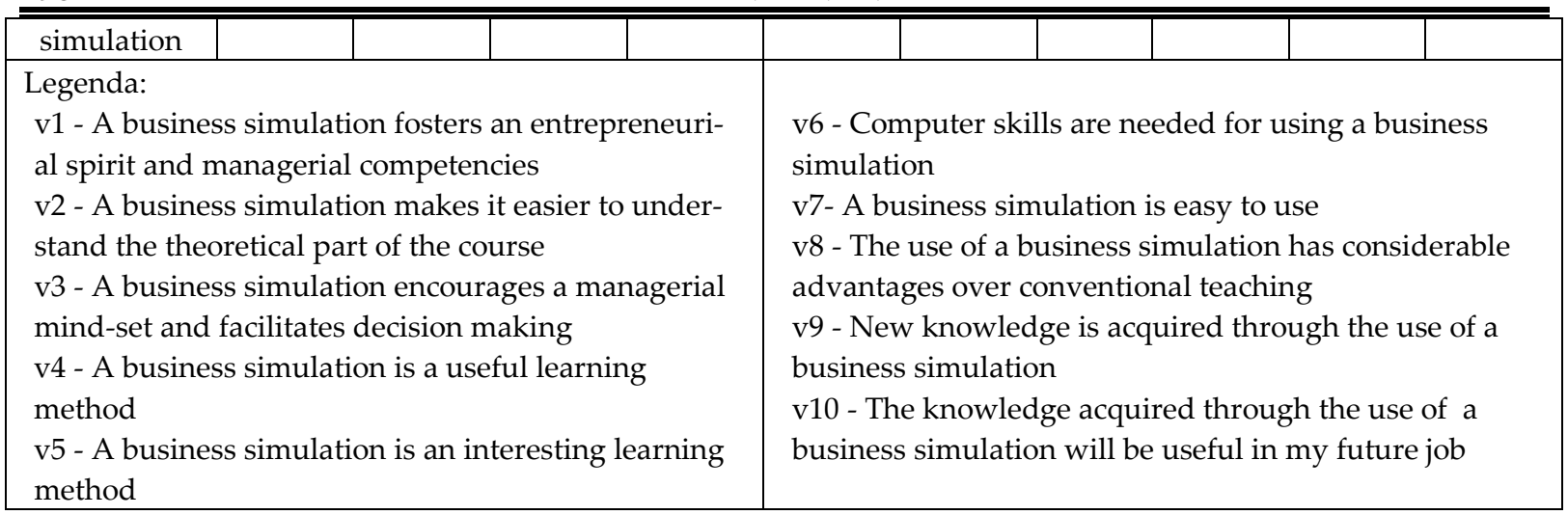

$* * p<0.01$

The correlations obtained indicate that satisfaction with the experience of using a business simulation is determined also by the assessment of the simulation's characteristics, because the values of the coefficients are statistically significant, indicating an association between the variables, with the exception of v7. To further study satisfaction with the use of a business simulation with regard to the creation of entrepreneurial knowledge, skills and competencies, factor analysis was conducted, by which the ten correlated original variables were reduced to two common factors. Prior to factor analysis, the correlation coefficient matrix was subjected to a statistical significance test using the Kaiser-Meyer-Olkin test and the Bartlett test that confirmed the suitability of the factor analysis method for the statistical processing of collected data. Factor analysis of the scale of satisfaction with the business simulation extracted two factors, which upon Varimax rotation with normalization explain about $52 \%$ of variance. Based on factor analysis and the content of statements, two sub-scales were formed: "Satisfaction with the outcomes of the business simulation" and "Satisfaction with the technical characteristics of the business simulation". Factor saturation levels are presented in the table below.

Table 3: Factor matrix of scale of satisfaction with the use of a business simulation

\begin{tabular}{|c|c|c|}
\hline \multirow[b]{2}{*}{ Item } & \multicolumn{2}{|c|}{ Components } \\
\hline & $\begin{array}{l}\text { Satisfaction with the } \\
\text { outcomes of the business } \\
\text { simulation }\end{array}$ & $\begin{array}{l}\text { Satisfaction with the } \\
\text { technical characteristics } \\
\text { of the business simula- } \\
\text { tion }\end{array}$ \\
\hline $\begin{array}{l}\text { 1. A business simulation fosters an entrepreneurial spirit } \\
\text { and managerial competencies }\end{array}$ & .711 & .068 \\
\hline $\begin{array}{l}\text { 2. A business simulation makes it easier to understand } \\
\text { the theoretical part of the course }\end{array}$ & .362 & .606 \\
\hline $\begin{array}{l}\text { 3. A business simulation encourages a managerial mind- } \\
\text { set and facilitates decision making }\end{array}$ & .589 & .463 \\
\hline 4. A business simulation is a useful learning method & .640 & .128 \\
\hline $\begin{array}{l}\text { 5. A business simulation is an interesting learning meth- } \\
\text { od }\end{array}$ & .398 & .512 \\
\hline $\begin{array}{l}\text { 6. Computer skills are needed for using a business simu- } \\
\text { lation }\end{array}$ & .160 & .481 \\
\hline 7. A business simulation is easy to use & -.347 & .769 \\
\hline $\begin{array}{l}\text { 8. The use of a business simulation has considerable ad- } \\
\text { vantages over conventional teaching }\end{array}$ & .814 & .010 \\
\hline
\end{tabular}




\begin{tabular}{|c|c|c|c|}
\hline & $\begin{array}{l}\text { New knowledge is acquired through the use of a } \\
\text { business simulation }\end{array}$ & .744 & .349 \\
\hline & $\begin{array}{l}\text { The knowledge acquired through the use of a busi- } \\
\text { ness simulation will be useful in my future job }\end{array}$ & .557 & .393 \\
\hline
\end{tabular}

Research method: Principle Component Analysis

Rotation: Varimax with Kaiser normalisation

The sub-scale "Satisfaction with the outcomes of the business simulation" is characterised by variables that foster the development of entrepreneurial skills and competencies during the use of the business simulation and variables that relate to the advantages of business simulations relative to conventional teaching. The sub-scale also focuses on the benefits of this learning method that enables students to acquire new knowledge that will be useful to them in their future jobs. The sub-scale "Satisfaction with the technical characteristics of the business simulation" is determined by variables referring to the ease of using business simulations and to the importance of the computer skills required for such use. The subscale is also defined by the variable relating to a business simulation as an interesting learning method and the variable referring to easier understanding of the theoretical part of the course through the use of a business simulation. The table below presents the basic statistical indicators of the two sub-scales.

Table 4: Basic statistical indicators of the sub-scales "Satisfaction with the outcomes of the business simulation" and "Satisfaction with the technical characteristics of the business simulation"

\begin{tabular}{|l|c|c|}
\hline \multicolumn{1}{|c|}{ Sub-scales } & MEAN & SD \\
\hline Satisfaction with the outcomes of the business simulation & 4.24 & .628 \\
\hline $\begin{array}{l}\text { Satisfaction with the technical characteristics of the busi- } \\
\text { ness simulation }\end{array}$ & 3.76 & .674 \\
\hline
\end{tabular}

The results of research show that satisfaction with the outcomes of the business simulation $(M=4.24)$ is greater than satisfaction with the technical characteristics of the simulation $(\mathrm{M}=3.76)$. These results indicate that the teaching method used in the field of entrepreneurial management should be adjusted to the varying and individual preferences of students, taking into consideration both the outcomes of the method applied and its technical characteristics.

\section{CONCLUSION}

The primary value of this study is in its deeper conceptualisation of a business simulation as an innovative teaching method in the field of entrepreneurial management. The aim of empirical research was to determine the students' level of satisfaction with the use of a business simulation in the teaching process of the course "Entrepreneurial Management and Innovation" at the Faculty of Tourism and
Hospitality Management of the University of Rijeka. At the same time, research aimed to establish the relationship between the perceived characteristics of business simulations and the level of satisfaction with the use of business simulations. Answers to the research questions formulated at the beginning of the paper were obtained using the appropriate statistical methods.

The results of research conducted are fully consistent with previous studies /34/; /35/;/36/; $/ 37 /$. The results confirm that a business simulation is a useful teaching method with a high level of acceptance in education in the field of entrepreneurial management. The advantage of using business simulations, in comparison with conventional teaching, was rated with the highest average score $(\mathrm{M}=4.52)$. Very high scores were also given to statements referring to the use of business simulations in developing entrepreneurial spirit and managerial competencies $(\mathrm{M}=4.22)$, in fostering a managerial mind-set and facilitating decision making 
$(\mathrm{M}=4.26)$ and in making it easier to master the theoretical part of the course $(\mathrm{M}=4.04)$. In addition, differences were established in expectations and satisfaction with using a business simulation, with overall satisfaction with the experience of using a business simulation receiving a higher average score $(\mathrm{M}=4.04)$ than prior expectations $(\mathrm{M}=3.95)$. The results of the study indicate that the evaluation of a business simulation is positively and significantly associated with the level of overall satisfaction with the use of the simulation. It can be concluded that the introduction of business simulations as an innovative teaching method is a sound step forward in improving the quality of teaching in educational practice. To achieve higher teaching quality, however, care should be taken to adjust the teaching method to the varying and individual preferences of students, with regard to both teaching method outcomes and the technical characteristics of the teaching method. Based on the conducted study, suggestions can be put forward that would be applicable in educational systems using innovative teaching methods. Considering that the variable $A$ business simulation is easy to use had the lowest score $(\mathrm{M}=2.76)$ and that fully $60 \%$ of the students reported the complexity of the business simulation to be a disadvantage, this should be taken into consideration when examining the factors that could contribute to making business simulations simpler to use. Some limiting factors, however, need to be stated regarding the results of the study. The research on satisfaction with the use of business simulations is spatially limited as it included only those students who used business simulations as part of the course "Entrepreneurial Management and Innovation" at the Faculty of Tourism and Hospitality Management. Accordingly, the spatial coverage of future research should, in addition to the students of the Faculty of Tourism and Hospitality Management, also include the students of other faculties that use business simulations as a teaching method in their courses. Another limitation of the study is the specific features of the business simulation implemented in the teaching process, making it impossible to generalise the research results.
The results of this study can contribute to improving existing knowledge and spreading the use of business simulations in educational practice, thus providing an opportunity to increase the competitiveness of future entrepreneurs in the labour market. With regard to the topicality of the research topic, which is fully in line with the trends in education, the findings of the study make advances in improving theoretical as well as applicable knowledge in education for entrepreneurs.

Notes

/1/ World Economic Forum. (2016). The future of jobs: Employment, skills and workforce strategy for the fourth industrial revolution. World Economic Forum, Geneva, Switzerland.

/2/ Hisrich, R. D., Peters, M. P., and Shepherd, D. A. (2011). Poduzetništvo. Mate.

/3/ EUROPE, E. I. (2003). Green Paper Entrepreneurship in Europe.

/4/ Brkanlić, S., Radakov, S., and Vapa, B. (2012). Metode aktivnog učenja u sistemu visokog obrazovanja. Učenje za poduzetništvo, 2(1), 171176.

/5/ Ahmed, A., and Sutton, M. J. (2017). Gamification, serious games, simulations, and immersive learning environments in knowledge management initiatives. World Journal of Science, Technology and Sustainable Development, 14(2/3), 78-83.

/6/ Geithner, S., i Menzel, D. (2016). Effectiveness of learning through experience and reflection in a project management simulation. Simulation i Gaming, 47(2), 228-256.

/7/ Kriz, W. C. (2003). Creating effective learning environments and learning organizations through gaming simulation design. Simulation i Gaming, 34, 495-511.

/8/ Obschonka, M. (2013). Entrepreneurship as 21st century skill: Taking a developmental perspective. In M. Coetzee (Ed.), Psycho-social career meta-capacities: Dynamics of contemporary career development (pp. 293-306). Amsterdam: Springer.

/9/ Baumol, W. J., Litan, R. E., and Schramm, C. J. (2007). Good capitalism, bad capitalism, and the economics of growth and prosperity. New Haven, CT: Yale University Press.

/10/ Schmitz, A., Urbano, D., Dandolini, G. A., de Souza, J. A., and Guerrero, M. (2017). Innovation and entrepreneurship in the academic setting: a systematic literature review. International Entrepreneurship and Management Journal, 13(2), 369-395. 
/11/ Clark, B. R. (1996). Substantive growth and innovative organization: new categories for higher education research. Higher Education, 32(4), 417-430.

/12/ van Vught, F. (1999). Innovative universities. Tertiary Education and Management, 5(4), 347354.

/13/ Clark, B. R. (1998). Creating entrepreneurial universities: organizational pathways of transformation. Oxford: Pergamon-Elsevier Science.

/14/ Etzkowitz, H., Webster, A., Gebhardt, C., and Terra, B. R. C. (2000). The future of the university and the university of the future: evolution of ivory tower to entrepreneurial paradigm. Research Policy, 29(2), 313-330

/15/ Etzkowitz, H. (2003a). Innovation in innovation: the triple helix of university-industrygovernment relations. Social Science Information, 42(3), 293-337.

/16/ Etzkowitz, H. (2003b). Research groups as Bquasi-firms ${ }^{\wedge}$ : the invention of the entrepreneurial university. Research Policy, 32(1), 109121.

/17/ Yusof, M., and Jain, K. K. (2010). Categories of university-level entrepreneurship: a literature survey. International Entrepreneurship and Management Journal, 6(1), 81-96.

/18/ Urbano, D., i Guerrero, M. (2013). Entrepreneurial universities: socioeconomic impacts of academic entrepreneurship in a European region. Economic Development Quarterly, 27(1), 40-55.

/19/ Schmitz, A., Urbano, D., Dandolini, G. A., de Souza, J. A., and Guerrero, M. (2017). op. cit., 369-395.

/20/ Perić, M., and Đurkin, J. (2012). Primjena poslovnih simulacija u visokoškolskom obrazovanju budućih menadžera $u$ turizmu i ugostiteljstvu. Učenje za poduzetništvo, 2(1), 161-169.

/21/ Ibidem

/22/ De Freitas, S., and Oliver, M. (2006). How can exploratory learning with games and simulations within the curriculum be most effectively evaluated? Computers i Education, 46, 249264.

/23/ Faria, A. J. (2001). The changing nature of business simulation/ gaming research: A brief history. Simulation i Gaming, 32, 97-110.
/24/ Stephen, J., Parente, D. H., and Brown, R. C. (2002). Seeing the forest and the trees: Balancing functional and integrative knowledge using large scale simulations in capstone business strategy classes. Journal of Management Education, 26, 164-193.

/25/ Feinstein, A. H., and Cannon, H. M. (2002). Constructs of simulation evaluation. Simulation i Gaming, 33, 425-440.

/26/ Gosen, J., and Washbush, J. (2004). A review on scholarship assessing experiential learning effectiveness. Simulation i Gaming, 35, 270-293.

/27/ Vogel, J. J., Vogel, D. S., Cannon-Bowers, J., Bowers, C. A., Muse, K., and Wright, M. (2006). Computer gaming and interactive simulations for learning: A meta-analysis. Journal of Educational Computing Research, 34, 229243.

/28/ Ferk Novaković, M., and Bogdanović, M. (2011). Razvoj poduzetničke kompetencije kroz korištenje poslovnih simulacija. Učenje za poduzetništvo, 1(1), 141-154.

/29/ Lovelace, K., Eggers, F., and Dyck, L. (2016). I do and I understand: Assessing the utility of web-based management simulations to develop critical thinking skills. Academy of Management Learning and Education, 15, 100-121.

/30/ Cadotte, E. R. (2016). Creating Value in Marketing and Business Simulations: An Author's Viewpoint. Journal of Marketing Education, 38(2), 119-129.

/31/ ibidem

/32/ Kolb, D. A. (2014). Experiential learning: Experience as the source of learning and development. FT press.

/33/ Ferk Novaković, M., and Bogdanović, M. op.cit., 141-154.

/34/ Faria, A. J. (2001). op.cit., 97-110.

/35/ De Freitas, S., and Oliver, M. (2006). How can exploratory learning with games and simulations within the curriculum be most effectively evaluated? Computers i Education, 46, 249264.

/36/ Ferk Novaković, M., and Bogdanović, M. op.cit., 141-154.

/37/ Geithner, S., i Menzel, D. (2016). op.cit., 228-256 